\title{
Factors Influencing the Intention of Recipient to Pay Back Education Loan in State Foundation
}

\section{Nurul Farhanah Mohd Idres, Hasnah Haron, and Hanafiah Ahmad}

Faculty of Industrial Management, Universiti Malaysia Pahang, Lebuhraya Tun Razak, 26300 Gambang, Pahang, Malaysia

\section{Abstract}

This paper explores the factors that influence the intention to pay back the education loan among students in a state foundation. Education loan is the primary source for the student in order to pursue their studies. The government has introduced many forms of financial assistance such as scholarship, grants and education loan. However, the loan recipients have faced difficulties in repaying the loan, which will affect the provider and future recipients. This is because, the loan provider will not be able to sponsor future students if they are not able to collect the loan from the loan recipients. This paper identifies attitude, parental influence, media awareness and perception of loan

Corresponding Author: Nurul Farhanah Mohd Idres nurulfarhanah2018@gmail.com

Received: 5 August 2019 Accepted: 14 August 2019 Published: 18 August 2019

Publishing services provided by Knowledge E

(c) Nurul Farhanah Mohd Idres et al. This article is distributed under the terms of the

commons Attribution License, which permits unrestricted use and redistribution provided that the original author and source are credited.

Selection and Peer-review unde the responsibility of the FGIC2019 Conference Committee.

\section{G OPEN ACCESS} agreement towards the intention to pay back the education loan. Theory of Planned Behavior (TPB) is suggested to be the underpinning theory of this study. Findings of the study can assist the state foundations on setting strategies to collect payment from the loan recipients.

Keywords: theory of planned behavior, repayment loan, education loan, intention to pay back loan, attitude, parental influence, media awareness, perception of loan agreement.

\section{Introduction}

Higher education in the world has become increasingly important not only for individuals, to enrich their lives and improve their status, but also for the greater society for economic prosperity, and the progress of good governance. Higher education improves the status and produces greater individual and community power through economic wealth, democratic progress and social justice. (Macmillan P. 2006). The Malaysian government has done many of initiatives in which to help the community especially the young generation to have a better education. As stated in the Budget 2018, that was presented by the 6th Prime Minister YBhg. Dato' Sri Najib Tun Razak, totaling RM 250 million is allocated for the educational purpose as overall to develop a Science, Technology Engineering and Mathematics (STEM) Centre which required the latest 
learning methods, enhance the module of Computer Science in secondary school and allocate about RM 190 million to upgrade almost 2,000 classes into to Century Smart Classroom.

Several studies have researched the impact of giving financial assistance. One of the studies of state and federal scholarship programs by Dynarski, (2008); Sjoquist \& Winters (2012) found sizable effects on college enrolment but less evident effects on college completion. Therefore, the government has provided various type of financial assistance such as scholarship and loan, grants and work-study program in order to encourage the student to further studies and graduated from college. Scholarships are offered to students based on students' talents, skills and academic achievements. Grants are basically given to students who need financial assistance, but the grant is almost replaced by recent student loans. According to Feng (2009), the number of student loans must be sufficient to ensure students can rely on them. The student will be able to complete the study if there is an adequate amount of loans given (Liu, Cheng \& Zhang, 2007) while if there is inadequate loan given, the students need to work as part-time to support their education or drop out of school during their studies. Therefore, financial aid program such as PTPTN, State Foundation, MARA, JPA, and MyBrain15 is needed so that they can pursue into the higher institution from an undergraduate level to a doctorate or professional courses. Malaysian Finance Minister mention that the budget allocation for education is one of the main financial sources for the students is by taking an education loan. Shen \& Ziderman (2009), said that an about 70 countries across the world are offered educational loan's scheme to the students who would like to pursue higher education and the education loan is different for each country in term of their objectives, the firm structure, source of funding, targeted students, amount of loans allocated to each of recipients, disbursement process and the collection process (Ziderman, 2004). Even there is a difference, most of the educational assistance across the countries have similarities in term of given a higher subsidized from the government itself. The National Higher Education Fund Corporation (PTPTN) is one of the main contributors to financial assistance. As of February 2019, as allocated RM56 billion as of February this year to help more than three million students to pursue their studies at institutions of higher learning (World Time News, 2019). State foundation also helping the student to pursue their education by giving the loan to the higher education level that more focus on their state residents. However, the issue of education loan repayment becomes a growing problem. As the number of borrowers increased, the concern towards the ability of loan repayment also increased in which Educational institutions around the world today still struggle to cope with the education debt problem. This is 
because in the study of Baum and O'Malley (2003), reported that most of the student feel burdened on education debt which leads to the repayment issue. According to Sarah $\&$ Rich (2018), $20 \%$ out of 8 million of the federal student loan borrowers in America are having difficulties in making the loan repayment. US Federal and state officials from both major political parties, researchers, advocates, and student loan provider acknowledge that the repayment and servicing systems have serious problems. In Malaysia, the Perak State Government are in debt of about RM17.5 million for education loan. In 2017, the former Chairman of Education, Science, Environment and Green \& Technology of state government mentioned that about 4,632 recipients have failed to pay back their loan and 20 loan recipients (less than 1\%) have been taken to court for action. It could be due to the low percentage of action taken against the loan defaulters that have made the issue of debt repayment a significant issue to be addressed. Most of the previous research studied the factors on why the recipient is not paying back the education loan but, the study on why the recipient intends to do the repayment still needs to be studied. Thus, this study will benefit to state foundation in term of knowing the right attitude that can influence the recipient to pay their loan while can keep maintaining the consistent payment by existing recipient.

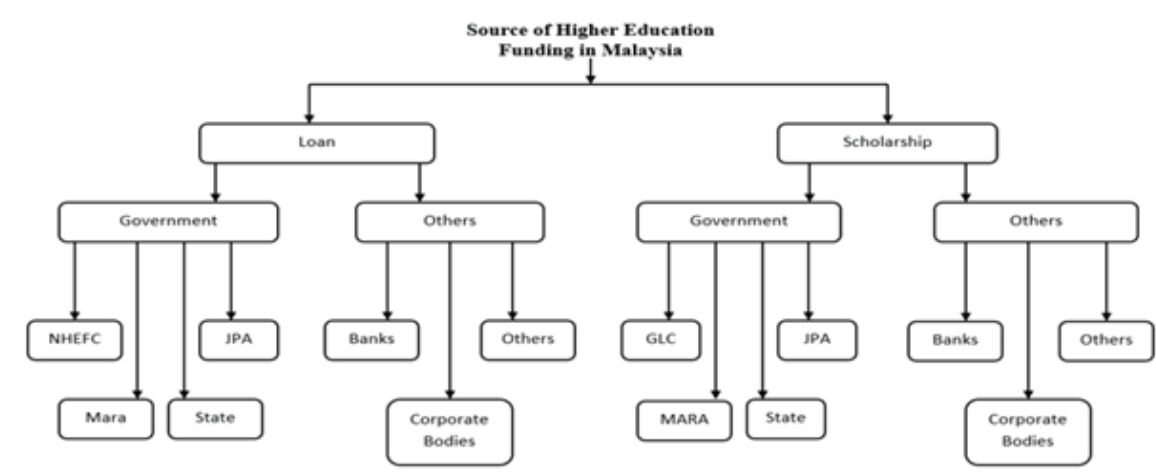

Figure 1: Sources Funding in of Higher Education at Malaysia (Source: Ismail S. (2011)).

\section{Literature Review}

The theory that is widely been used in the attitude study that explains the relationship of the factors influencing intention to payback loan is the Theory of Planned Behavior. TPB illustrates that a person's performance on behavior is determined by his intention towards that behavior. This study will use TPB to explain the relationship of the factors that influence intention among the recipient which measure students' attitude. If the individual has more favorable attitudes toward a particular behavior, he will have the 
intention to make his/her loan repayment. Unlikely, for unfavorable attitudes of individuals towards a particular behavior, he will not more likely intend to perform his behavior. Subjective norms refer to the perceptions of the person and influence whether his behavior is affected by others or not. (Ajzen, 2006). This study will measure subjective norms through parental and awareness whether it influences the student intends to make a loan repayment. Perceived Behavioral Control (PBC) is a measurement of the people perceptions of performing a behavior of interest' Ajzen (2011). The extent that individuals could successfully transform their behavioral intention into actual behavior much depends on their perception. Perceived behavioral control in this study refers to a perceived agreement.

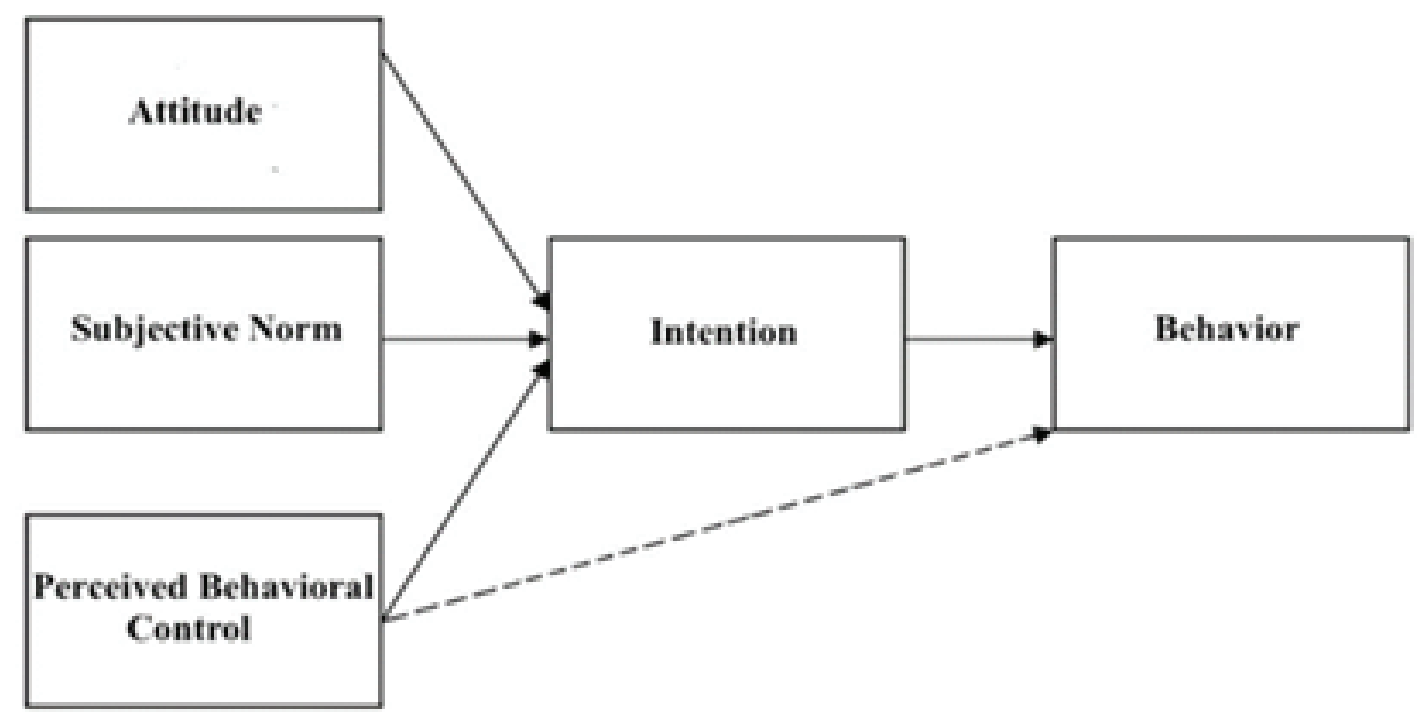

Figure 2: Theory of Planned Behavior (TPB).

\subsection{Factors influencing the intention to pay back education loan}

Several studies have examined attitudes toward educational loans and student debt in general (Chudry, Foxall, \& Pallister, 2011; Davies \& Lea, 1995; Haultain, Kemp, \& Chernyshenko, 2010). A qualitative study, Chudry et al. (2011) explores the factors that influence the attitude of borrowing scholars and finds that students consider educational loans to improve their future, rather than the form of debt. Parents play a role in shaping student attitudes towards general debt (Chudry et al., 2011) and credit card debt (Norvilitis \& MacLean, 2010). A study using a British sample found that students' debt levels rose sharply between the second and third years of college, and once students incurred debt, their attitudes toward debt became more tolerant (Davies \& Lea, 1995). Although attitudes toward debt had been either positive or negative, a 
psychological structure of attitudes toward debt and higher education was suggested to be multidimensional (Haultain et al., 2010). In three studies on New Zealand tertiary students, Haultain et al. found that two dimensions, fear of debt and debt utility, were associated with how debt was described. Zainal et al. (2012) has conducted a study and found that the student predicted to have negative attitudes on paying back their education loan. This is because most of the recipient does not take the education loan as their priority, but it was ranked at fifth after other types of expenses listed. Another study by O'Loughin et al. (2006) that tries to explore current perspective on the way of behaving related to student credit and debt consumption between the United Kingdom (UK) and Irish students found that students who are living in credit led environment to have effects on student's perceptions and behaviors concerning credit and debt consumption.

TABLE 1: Factors affecting intention to do loan repayment.

\begin{tabular}{|c|c|c|c|}
\hline Authors & $\begin{array}{l}\text { Independent } \\
\text { Variable }\end{array}$ & Methodology & Findings \\
\hline $\begin{array}{l}\text { Edward Wong Sek } \\
\text { Khin, Ahmad } \\
\text { Nasharuddin \& } \\
\text { Kamisah Binti } \\
\text { Ismail (2015) }\end{array}$ & $\begin{array}{l}\text { Attitude } \\
\text { Awareness } \\
\text { Perception of } \\
\text { Affordability } \\
\text { Perception of Ioan } \\
\text { agreement }\end{array}$ & $\begin{array}{l}\text { A questionnaire } \\
\text { distributed to } 300 \\
\text { participants who } \\
\text { graduated from one of } \\
\text { the public universities } \\
\text { in Malaysia }\end{array}$ & $\begin{array}{l}\text { Attitude towards education loan } \\
\text { repayment has a positive } \\
\text { relationship with the intention to } \\
\text { repay PTPTN loan. } \\
\text { Awareness of PTPTN issues created } \\
\text { by the media has a positive } \\
\text { relationship with the intention to } \\
\text { repay PTPTN loan. } \\
\text { Perceived affordability of repayment } \\
\text { after graduating has a positive } \\
\text { relationship with the intention to } \\
\text { repay PTPTN loan. } \\
\text { Perception towards loan agreement } \\
\text { has a positive relationship with the } \\
\text { intention to repay PTPTN loan }\end{array}$ \\
\hline $\begin{array}{l}\text { Safinar Ismail } \\
\text { (2011) }\end{array}$ & $\begin{array}{l}\text { Student Attitude } \\
\text { Parental Influence } \\
\text { Perception that } \\
\text { loan repayment } \\
\text { will affect quality } \\
\text { of life after } \\
\text { graduation } \\
\text { Perception } \\
\text { towards loan } \\
\text { agreement is } \\
\text { positively } \\
\text { influence } \\
\text { perception that } \\
\text { loan repayment } \\
\text { will affect quality } \\
\text { of life after } \\
\text { graduation }\end{array}$ & $\begin{array}{l}\text { Mixed-Method } \\
\text { Qualitative Approach } \\
\text { Semi-Structured } \\
\text { Interviews } \\
\text { Purposive Sampling } \\
\text { Quantitative Approach } \\
\text { Survey }\end{array}$ & $\begin{array}{l}\text { Students' attitude has been found in } \\
\text { this study to have a significant } \\
\text { impact on the intention to repay the } \\
\text { loan. } \\
\text { Parental influence is associated } \\
\text { significantly with the intention to } \\
\text { repay loan. } \\
\text { The relationships between } \\
\text { perceived quality and the intention } \\
\text { is significant } \\
\text { Hypothesizes the relationship } \\
\text { between perceived agreement and } \\
\text { perceived quality, which is found to } \\
\text { be significant }\end{array}$ \\
\hline
\end{tabular}




\begin{tabular}{|c|c|c|c|}
\hline Authors & $\begin{array}{l}\text { Independent } \\
\text { Variable }\end{array}$ & Methodology & Findings \\
\hline $\begin{array}{l}\text { Siti Zulaikha } \\
\text { Zolkeplee, Abu } \\
\text { Bakar Hamed \& } \\
\text { Ahamad Faosiy } \\
\text { Ogunbado (2018) }\end{array}$ & $\begin{array}{l}\text { Anxiety, } \\
\text { Parental } \\
\text { Influence, } \\
\text { Media awareness, } \\
\text { Religiosity }\end{array}$ & $\begin{array}{l}\text { The data was collected } \\
359 \text { from Universiti } \\
\text { Utara Malaysia (UUM) } \\
\text { Muslims' } \\
\text { undergraduate } \\
\text { students who had } \\
\text { taken the National } \\
\text { Higher Education Fund } \\
\text { Corporation } \\
\text { (NHFEC) financing } \\
\text { during their studies. }\end{array}$ & $\begin{array}{l}\text { the anxiety variable is not significant } \\
\text { to the dependent variable of } \\
\text { student's perception towards } \\
\text { educational loan repayment. } \\
\text { The parental influence variable } \\
\text { recorded positive influence on } \\
\text { student's perception towards } \\
\text { educational loan repayment, but the } \\
\text { relationship is not as strong as } \\
\text { religiosity. } \\
\text { Media awareness variable also } \\
\text { showed a positive influence on } \\
\text { student's perception towards } \\
\text { educational loan repayment } \\
\text { religiosity is the most influential } \\
\text { variable on student's perception } \\
\text { towards educational loan } \\
\text { repayment. }\end{array}$ \\
\hline $\begin{array}{l}\text { Ahmad Harith } \\
\text { Ashrofie Hanafi, } \\
\text { Wan Rozima Mior } \\
\text { Ahmed Shahimi, } \\
\text { Muhammad } \\
\text { Ashraf Anuar, } \\
\text { Kuah Yoke Chin, } \\
\text { \& Shum Shen } \\
\text { Hwei (2018) }\end{array}$ & $\begin{array}{l}\text { Awareness } \\
\text { created by media } \\
\text { Human Interaction } \\
\text { Attitude } \\
\text { Repayment } \\
\text { Alternatives }\end{array}$ & $\begin{array}{l}\text { A total of } 500 \\
\text { questionnaires were } \\
\text { distributed to academic } \\
\text { and non-academic } \\
\text { staffs in the whole of } \\
\text { Malaysia by using } \\
\text { convenience sampling } \\
\text { technique out of which } \\
215 \text { responses were } \\
\text { collected. }\end{array}$ & $\begin{array}{l}\text { The findings showed that the } \\
\text { borrower's attitude, awareness from } \\
\text { media and repayment alternatives } \\
\text { but not human interaction were the } \\
\text { factors that influenced the } \\
\text { borrower's intention to repay PTPTN } \\
\text { loan. }\end{array}$ \\
\hline
\end{tabular}

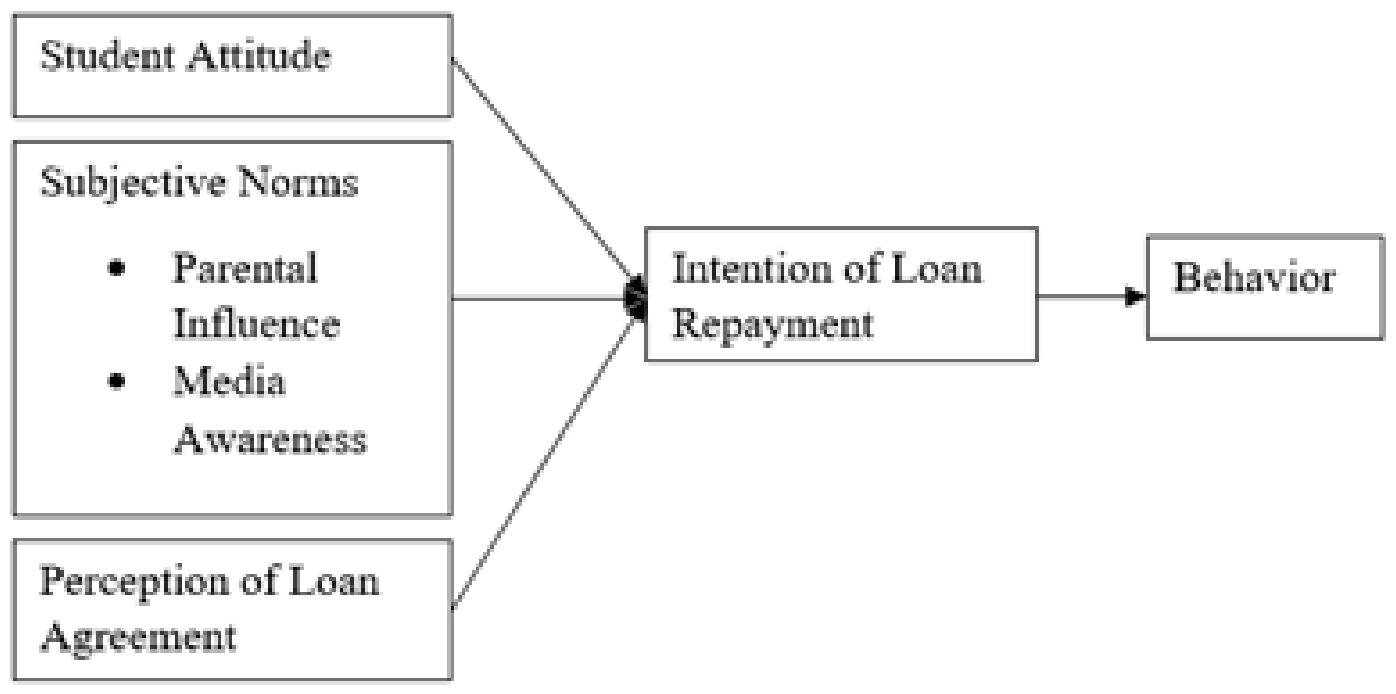

Figure 3: Conceptual Framework. 


\subsection{Hypotheses Development}

A study by Khin E.N.S., Nasharuddin K., \& Ismail K. (2015) stated that attitude towards education loan repayment has a positive relationship with the intention to repay PTPTN Ioan. Another study by Ismail S. (2011) also found that students' attitude has been found in this study to have a significant impact on the intention to repay the loan. The findings are also supported by studies from Hanafi A.H.A, Ahmad Shahimi W.R.M., Annual M.A, Chin K.Y \& Hari S.S. (2018). Thus, it hypothesized that:

$\mathrm{H1}$ : There is a significant relationship between student attitudes towards intention to pay back education loan.

In many studies conducted in Malaysia (Ramayah et al., 2003, 2004; Yulihasri, 2004; Gopi and Ramayah, 2007) it has been shown that subjective norm is a significant predictor of intention to use in the Malaysian context. As found in Zolkeplee S.Z., Hameed A.B \& Ogunbado (2018) study, it showed that parental influence variable recorded positive influence on student's perception towards educational loan repayment. Ismail S. (2011) also found that parental influence is associated with significantly repay a loan. Thus, it hypothesized that:

$\mathrm{H} 2$ : There is a significant relationship between parental influences towards intention to pay back education loan.

Hanafi A.H.A, Ahmad Shahimi W.R.M., Annual M.A, Chin K.Y \& Hari S.S. (2018) found that awareness from media influenced the borrower's intention to repay PTPTN loan. Thus, it hypothesized that:

H3: There is a significant relationship between media awareness towards the intention to pay back education loan.

A study carried out by Abu Bakar et al. (2006) stated that group of students who manage to get good results in their studies for example cumulative grade point average (CGPA) above 3.0 has better knowledge concerning loan agreements than those who obtained poor results or a CGPA lower than 3.0. Several studies in the USA found that senior students have better knowledge compared to first-year students regarding certain aspects of their education loan (Hira et al., 2000).

H4: There is a significant relationship between knowledge on loan agreement towards the intention to pay back education loan. 


\section{Conclusion}

The past studies have shown that many factors can measure an individual's intention. Therefore, this study proposes to use TPB to explain the relationship of student's attitude, parental influence, media awareness and perception on loan agreement to measure students' intention to pay back their loan. Findings of the study will assist the state foundations on strategies to collect the loan.

\section{Acknowledgement}

We would like to thank Yayasan Bank Rakyat for the financial support by sponsoring this paper to be presented in the FGIC $2^{\text {nd }}$ Conference on Governance and Integrity 2019.

\section{References}

[1] Abu Bakar, E., Masud, J. \& Jusoh M.Z. (2006), 'Knowledge, attitude and perceptions of university students towards educational loans in Malaysia', Journal of family economics issue, Vol. 27, pp. 692-701

[2] Ajzen, I., \& Fishbein, M. (1980). Understanding attitudes and predicting social behavior. Englewood Cliffs, NJ: Prentice-Hall

[3] Ajzen, I. (1991). Theory of planned behavior. Organizational behavior and human decision processes. 50, 179-211

[4] Ajzen, I. (2006). Constructing a TpB Questionnaire: Conceptual and Methodological Considerations. Retrieved June 27, 2011 from the World Wide Web: http://www. people.umass.edu/aizen/pdf/tpb.measurement.pdf.

[5] Ajzen I (2011) The theory of planned behaviour: reactions and reflections. Psychol Health 26: 1113-1127.

[6] Baum, S. \& O'Malley, M. (2003). College on credit: How borrowers perceive their education debt:

[7] Results of the 2002 National Student Loan Survey, Nellie Mae Corporation, Braintree, MA.

[8] Chudry, F., Foxall, G. \& Pallister, J. (2011). Exploring attitudes and predicting intentions: profiling student debtors using an extended theory of planned behavior. Journal of Applied Social Psychology, 41, 119-149. 
[9] Davies, E. \& Lea, S. (1995). Student attitudes to student debt. Journal of Economic Psychology, 16,663-679.

[10] Dillon, E. \& Smiles, R.V. (2010), Lowering student loan default rates: what one consortium of historically black institutions did to succeed, Education Sector

[11] Gopi, M. and Ramayah, T. (2007), "Applicability of theory of planned behavior in predicting intention to trade online: some evidence from a developing country", International Journal of Emerging Markets, Vol. 2 No. 4, pp. 348-60

[12] Wong, S. K. E., Nasharuddin, A., \& Ismail, K. (2015). Education loan repayment and performances: The Malaysian graduate's perspectives. Jati-Journal of Southeast Asian Studies, 20, 158-172.

[13] Feng.T (2009): The investigation of Student Loan Program in China. ISBN 978-780745-526-4.

[14] Fishbein, M., \& Ajzen, I. (1975). Belief, attitude, intention and behavior: An introduction to theory and research. Reading, MA: Addison-Wesley.

[15] Haultain, S., Kemp, S. \& Chernishenko, O. (2010). The structure of attitudes to student debt. Journal of Economic Psychology, 31, 322-330.

[16] Hira, T.K., Anderson, M.M., \& Petersen, K. (2000). Students' perceptions of their education debt and its impact on life after graduation. Journal of Student Financial Aid, 30(1), 7-19.

[17] Liu, X., Luo, R., Liu, C., \& Zhang, L. (2007). The cost of going to senior high schools in rural China. Working Paper WP-07-C8, Northwest Socio-economic Development Research Center, Shaanxi, China. Levy, D. C. (2010).

[18] Macmillan P. (2006). Higher Education in The World, The Financing of Universities. Great Britain, William cloves, First edition.

[19] Manstead, A.S., Proffitt, C. \& Smart, J.L. (1983). Predicting and understanding mothers' infant-feeding intentions and behavior: Testing the theory of reasoned action. Journal of Personality and Social Psychology, 44(4), 657-671.

[20] Norvilitis, J., Merwin, M., Osberg, M., Roehling, P., Young, P. \& Kamas, M. (2006) Personality factors, money attitudes, financial knowledge and credit-card debt in college students. Journal of Applied Social Psychology 36, 1395-1413.

[21] O'Loughlin, D. \& Szmigin, I. (2006). “I'll always be in debt”: Irish and UK student behaviour in a credit led environment. Journal of Consumer Marketing, 23(6), 335343.

[22] Ramayah, T., Jantan, M., Noor, N., Razak, R.C. and Ling, K.P. (2003), "Receptiveness of Internet banking by Malaysian consumers", Asian Academy of Management Journal, Vol. 8 No. 2, pp. 1-29. 
[23] Ramayah, T., Aafaqi, B. and Ignatius, J. (2004), "Role of self-efficacy in e-library usage among students of a public university in Malaysia", Malaysian Journal of Library and Information Science, Vol. 9 No. 1, pp. 39-57.

[24] Ismail, S., Serguieva, A., \& Singh, S. (2010). Students' Attitude towards Loan Repayment: A Theoretical Framework. Journal of Economics and Development, Faculty of Economics, Sabelas Maret University (ISSN: 1410-1815).

[25] Sarver, V.T. (1983). Ajzen and Fishbein's "theory of reasoned action": A critical assessment. Journal for the Theory of Social Behaviour, 13(2), 155-163

[26] Shen, H. \& Ziderman, A. (2009). Student loans repayment and recovery: International comparisons. Higher Education. 57(3), 315-333

[27] Yulihasri, T. (2004), "Retailing on internet: the buying intention", MBA thesis, School of Management, University Sains Malaysia, Penang

[28] Zainal, N. R. \& Ismail, N. (2012). Debt composition and attitude towards education loan among Malaysian graduates. Procedia - Social and Behavioral Sciences, 36(2012), 280-286

[29] Ziderman, A. (2004). Policy options for student loan schemes: lessons from five Asian case studies. International Institute for Educational Planning. Paris: UNESCO. 